\title{
Intussusception Caused by an Appendiceal Mucocele: Case Report
}

\section{Appendiks Mukoseline Bağlı Intussusepsiyon: Olgu Sunumu}

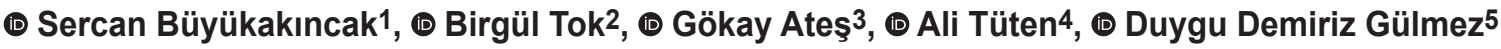 \\ ${ }^{1}$ Akçaabat Haçkalı Baba State Hospital, Clinic of General Surgery, Trabzon, Turkey \\ ${ }^{2}$ Akçaabat Haçkalı Baba State Hospital, Clinic of Pathology, Trabzon, Turkey \\ ${ }^{3}$ Akçaabat Haçkalı Baba State Hospital, Clinic of Anaesthesiology, Trabzon, Turkey \\ ${ }^{4}$ Akçaabat Haçkalı Baba State Hospital, Clinic of Radiology, Trabzon, Turkey \\ 5 Opr. Dr. Ergun Özdemir Görele State Hospital, Clinic of Anaesthesiology, Trabzon, Turkey
}

\section{HIIIIII| ABSTRACT}

Intussusception of the appendix in to the caecum caused by an appendiceal mucocele is a rarecondition. Acute appendicitis is the most common presentation is of the disease. Radiologic examination methods especially computed tomography can be useful for preoperative diagnosis. If a mucocele is more than $2 \mathrm{~cm}$ in size or caused intessuception, right hemicolectomy should be considered.

Keywords: Appendix, mucocele, intussuception

\section{|HIIIIII| ÖZ}

Appendiks mukoseli nedeniyle gelişen appendiksin çekuma intussusepsiyonu oldukça nadirdir. En sık akut apandisit kliniği ile ortaya çıkar. Ameliyat öncesi dönemde tanı görüntüleme yöntemleri ile özellikle de bilgisayarlı tomografi ile konulabilmektedir. Appendiks mukoselinin çapı 2 cm'yi aştığı durumlarda veya intussusepsiyon bulunması durumunda sağ hemikolektomi önerilmektedir.

Anahtar Kelimeler: Appendiks, mukosel, intussusepsiyon

\section{Introduction}

Appendiceal cecal intussusception is rare and occurs in about $0.01 \%$ of patients undergoing appendectomy ${ }^{1}$. Appendiceal intussusceptions may develop due to foreign bodies, lymphoid hyperplasia, polyps, neoplasia and endometriosis ${ }^{2}$. Intussusception due to appendiceal mucocele is quite rare. We aimed to present a case who presented with acute appendicitis and was found to have cecal intussusception due to appendiceal mucocele in preoperative imaging methods.

\section{Case Report}

A 47-year-old male patient presented to our hospital with a complaint of abdominal pain that started 3 days ago. Physical examination revealed tenderness and defense in the right lower quadrant. In the laboratory parameters, the leukocyte count was $13.5 \times 10^{3} / \mu \mathrm{L}$ (95\% neutrophil). Other biochemical markers were normal. Ultrasonography revealed a pathological mass in the right lower quadrant of the abdomen. On computed tomography, appendiceal mucocele with a $15 \mathrm{~cm}$ length and diameter of $5.2 \mathrm{~cm}$ was found to cause intestinal intussusception (Figure 1). The patient was taken to the operation and exploration led to the right hemicolectomy because the tumor extended to the base of the appendix and caused intussusception in the cecum (Figure 2). On postoperative day 7, the patient was discharged uneventfully. Histopathological examination revealed low grade mucinous neoplasm. 


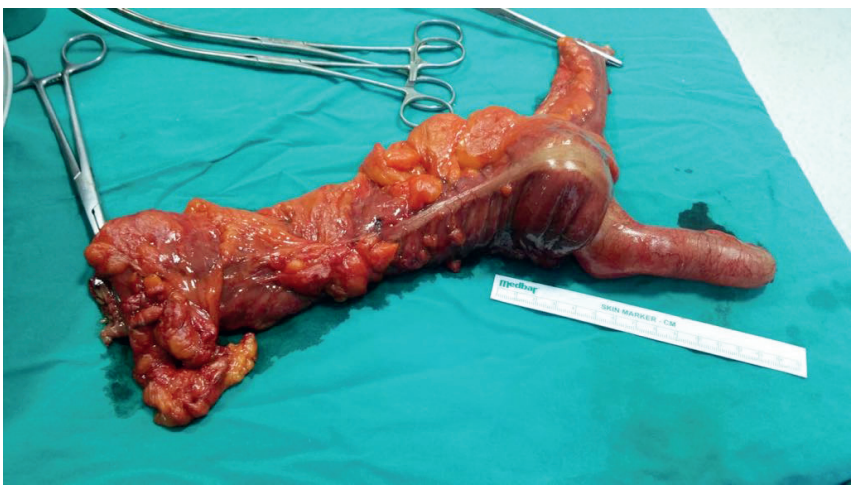

Figure 1. Right hemicolectomy line

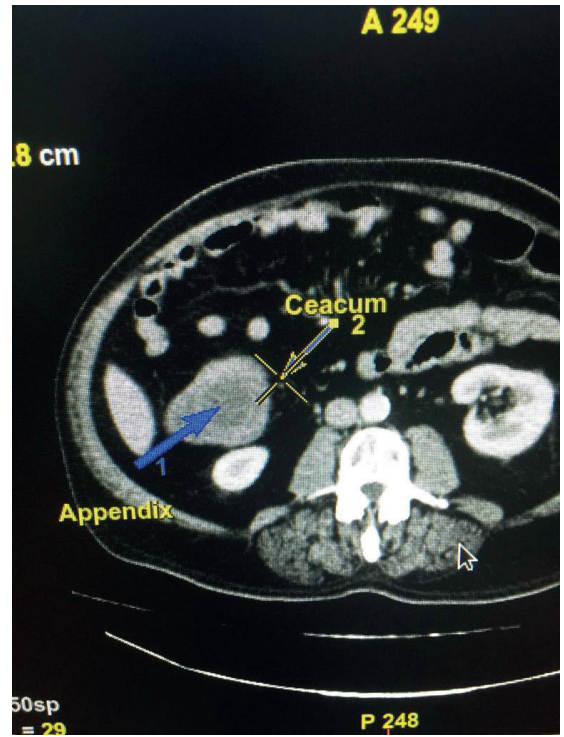

Figure 2. Appendiceal mucocele leading to intussusepision in a computed tomography

\section{Discussion}

Appendiceal cecal intussusception is very rare and occurs in approximately $0.01 \%$ of patients undergoing appendectomy. ${ }^{1}$ Appendiceal intussusception may develop due to foreign bodies, lymphoid hyperplasia, polyps, neoplasia and endometriosis. ${ }^{2}$ Appendiceal intussusception gives very different findings but often occurs as acute appendicitis. It is difficult to diagnose preoperatively due to the lack of clinical symptoms and findings. Imaging methods play an important role in preoperative diagnosis. Ultrasonography can detect intussusception, but computed tomography is the most sensitive imaging modality for detecting and diagnosing other underlying lesions. ${ }^{3}$ Computed tomography is typically detected as a mass or target lesion in the cecum. ${ }^{4}$

Appendiceal mucocele is a rare lesion and the incidence of appendectomies is between 0.2-0.3\%..$^{5}$ Appendiceal mucocele occurs in the form of a cystic mass in the appendiceal lumen expanding as a result of abnormal mucin deposition. The mucocele may be benign or malignant.
Benign mucinous cystadenoma is the most common. Malignant mucinous cyst adenocarcinoma is detected in 11$20 \%$ of the cases and spontaneous rupture has been reported in $6 \%$ of cases by causing severe dilatation of the appendix. ${ }^{6}$ The development of appendiceal pseudomyxoma peritonei due to spontaneous or iatrogenic perforation is associated with malignancy. ${ }^{7}$ Appendectomy is usually sufficient in most appendix tumors. Right hemicolectomy should be performed in patients with malignant mucinous lesion or when the benign lesion invades the appendix base. Right hemicolectomy is recommended considering the risk of progression to malignancy when the mucocele exceeds $2 \mathrm{~cm}$ in diameter. ${ }^{7}$ Reduction should be avoided by considering the risk of rupture when the appendix mucosal intussusception is detected. ${ }^{8}$

In our case, we planned right hemicolectomy because the appendix mucocele reached approximately $5 \mathrm{~cm}$ in diameter and intussusception was found.

\section{Ethics}

Informed Consent: Consent form was filled out by all participants.

Peer-review: Externally peer-reviewed.

\section{Authorship Contributions}

Surgical and Medical Application: S.B., G.A., Concept: S.B., B.T., Design: B.T., D.D.G., Data Collection: B.T., A.T., Analysis or Interpretation: A.T., D.D.G., Literature Search: S.B., B.T., Writing: S.B.

Conflict of Interest: No conflict of interest was declared by the authors.

Financial Disclosure: The authors declared that this study received no financial support.

\section{References}

1. Langsam LB, Raj PK, Galang CF. Intussusception of the appendix. Dis Colon Rectum 1984;27:387-392.

2. Uncu H, Taner D. Appendiceal endometriosis: two case reports. Arch Gynecol Obstet 2008;278:273-275.

3. Kim YH, Blake MA, Harisinghani MG, Archer-Arroyo K, Hahn PF, Pitman MB, Mueller PR. Adult intestinal intussusception: CT appearances and identification of a causative lead point. Radiographics 2006;26:733-744.

4. Ijaz S, Lidder S, Mohamid W, Carter M, Thompson H. Intussusception of the appendix secondary to endometriosis: a case report. J Med Case Rep 200822;2:12.

5. Winslow BT, Westfall JM, Nicholas RA. Intussusception. American Family Physician 1996:54;213-217

6. Rampone B, Roviello F, Marrelli D, Pinto E. Giant appendiceal mucocele: report of a case and brief review. World J Gastroenterol 2005;11:47614763.

7. Stocchi L, Wolff B, Larson D, Harrington JR. Surgical treatment of appendiceal mucocele. Arch Surg 2003;138:585-589

8. Chaar CI, Wexelman B, Zuckerman K, Longo W. Intussusception of the appendix: comprehensive review of the literature. Am J Surg 2009;198:122128. 